\title{
Avoiding Transfusion in 700 consecutive Outpatient Spine Surgery Patients Using Less Exposure Surgery Techniques
}

\author{
FJR Pencle ${ }^{1}$, NT Britton ${ }^{1}$, CF Packer ${ }^{1}$, JA Seale ${ }^{4}$, KR Chin ${ }^{2,3,4}$
}

\begin{abstract}
Objective: Spine surgery is transitioning using minimally invasive and less exposure surgery (LES) techniques. Blood loss requiring transfusions remains a distinct complication. The authors aim to demonstrate the use of tips and techniques in decreasing the risk of transfusion in the outpatient setting.

Methods: The databases of 1512 outpatient spine cases in a single surgeon study were reviewed between 2011 and 2015. We excluded from our analysis, all cervical and lumbar epidural steroid injections as well as, discograms, rhizotomies and non-spine orthopaedic procedures (total 812). Results: Of a total, of 700 total spine surgery cases, 300 (43\%) of all spine surgeries were performed in Group 1 (cervical spine) and 400 (57\%) in Group 2 (lumbar spine). Females represented 49\% of the overall patient population (Group 1: 146, Group 2: 197). The mean overall age was $49.2 \pm 0.8$, mean age Group 1 was $50.6 \pm 0.9$ and Group 2 was $47.1 \pm 1.2$. Mean overall body mass index (BMI) was $24 \pm 0.4$, Group 1 mean BMI was $21.0 \pm 0.7$ and Group 2 BMI was $26.1 \pm 0.3$. The overall length of surgery was 77.4 , Group 1: $65.8 \pm 2.1$ and Group 2: $89.0 \pm 1.5$. The mean overall estimated blood loss was 52.4 \pm 1.7 , Group 1: $43.3 \pm 2.4$ and Group 2: $55.4 \pm 2.1$. Blood loss demonstrated significant dependence on length of surgery, $\mathrm{p}<0.0001$ with dependence $R=0.451$.

Conclusion: This study has demonstrated using several tips and techniques, reduction of blood loss requiring the need for transfusions. Other factors to consider include patient selection and preoperative preparation for elective spine surgery.
\end{abstract}

Keywords: Blood loss, inpatient, less exposure surgery, outpatient, risk reduction, transfusion

\section{Evitar la transfusión en $\mathbf{7 0 0}$ pacientes consecutivos ambulatorios de cirugía de la columna usando técnicas de cirugía de menos exposición}

\author{
FJR Pencle ${ }^{1}$, NT Britton ${ }^{1}$, CF Packer ${ }^{1}$, JA Seale ${ }^{4}$, KR Chin ${ }^{2,3,4}$
}

\begin{abstract}
RESUMEN
Objetivo: La cirugía de la columna transita al uso de técnicas de cirugía mínimamente invasiva y técnicas de cirugía de menos exposición (CME). La pérdida de sangre que requiere transfusiones sigue siendo una complicación diferente. Los autores persiguen demostrar el uso de consejos y técnicas para disminuir el riesgo de la transfusión en el contexto ambulatorio.

Métodos: Se revisaron las bases de datos de 1512 casos de pacientes de columna tratados de manera ambulatoria en un estudio de un solo cirujano, entre 2011 y 2015. Se excluyeron de nuestro análisis, todas las inyecciones esteroides epidurales cervicales y lumbares, así como discogramas, rizotomías, y procedimientos ortopédicos no espinales (total: 812).
\end{abstract}

From: ${ }^{1}$ Charles E. Schmidt College of Medicine at Florida Atlantic University, USA, ${ }^{2}$ Herbert Wertheim College of Medicine at Florida International University, USA, ${ }^{3}$ Less Exposure Surgery Specialists Institute (LESS Institute), USA and ${ }^{4}$ Less Exposure Surgery (LES) Society, USA.
Correspondence: Dr K Chin, Less Exposure Surgery Specialists Institute (LESS Institute), 1100 W. Oakland Park Blvd. Suite \#3, Fort Lauderdale, FL, 33311, USA. Email: kingsleychin@thelessinstitute. com 
Resultados: De un total de 700 casos de cirugía de la columna total, 300 (43\%) de todas las cirugías de columna vertebral se realizaron en el Grupo 1 (columna cervical) y 400 (57\%) en el Grupo 2 (columna lumbar). Las hembras representaron el $49 \%$ de la población general de pacientes (Grupo 1:146, Grupo 2:197). La edad promedio general fue 49.2 \pm 0.8 , la edad promedio del Grupo 1 fue 50.6 \pm 0.9 , y la del Grupo 2 fue $47.1 \pm 1.2$. El indice de masa corporal (IMC) general promedio fue $24 \pm 0.4$, el IMC promedio del Grupo 1 fue 21.0 \pm 0.7 , y el IMC del Grupo 2 fue 26.1 \pm 0.3. La duración general de la cirugía fue 77.4, Grupo 1: $65.8 \pm 2.1$ y Grupo 2: $89.0 \pm 1.5$. La pérdida de sangre general promedio estimada fue 52.4 \pm 1.7, Grupo 1: 43.3 \pm 2.4, y Grupo 2: 55.4 \pm 2.1. La pérdida de sangre demostró una dependencia significativa respecto de la duración de la cirugía, $\mathrm{p}<0.0001$ con dependencia $R=0.451$.

Conclusión: Este estudio ha demostrado el uso de varios consejos y técnicas, y de la reducción de las pérdidas de sangre que requieren la necesidad de transfusiones. Otros factores a considerar incluyen la selección del paciente y su preparación preoperatoria para la cirugía electiva de la columna vertebral.

Palabras claves: pérdida de sangre, intrahospitalario, cirugía de menos exposición, ambulatorio, reducción del riesgo, transfusión

\section{West Indian Med J 2017; 66 (3): 425}

\section{INTRODUCTION}

The risk of blood loss requiring transfusion is a distinct possibility given the complexity of spine surgery procedures $(1,2)$. Transitioning spine surgery from inpatient to the outpatient setting faces the challenge of minimizing blood loss (3-5). Reducing the amount of blood loss in spinal surgery is a factor that has been demonstrated in the inpatient setting with varying products and techniques studied (6).

Several suggested techniques that reduce blood loss resulting in transfusion include stopping analgesics, supplements and some non-prescription medication two weeks prior to surgery (1). Some techniques to conserve blood are: the use of pre-operative autologous blood donation, appropriate patient's position, adequate muscle paralysis to minimize abdominal infiltration of paraspinal tissue, controlled hypotensive anaesthesia and anti-fibrinolytic agents (2). Techniques in complex spine surgery include, red blood cell augmentation, intra-operative anti-fibrinolytic administration, use of topical haemostatic agents, and intra-operative and postoperative blood salvage (7). General considerations for minimizing blood loss include autologous transfusion therapy, intra-operative and postoperative blood salvage, pharmacologic manipulation of the coagulation cascade and controlled hypotension (8).

Increasing data suggest that surgical blood loss occurs for many reasons including the muscles and bones, bleeding from the exposure of the spine, adult patients with arthritic facet joint and stiffer spines possibly requiring osteotomy (1). Blood products have several possible complications such as impairing the immune system, therefore increasing the infection rate after surgery, coagulopathy or disseminated intravascular coagulation [DIC] (1). The authors aim to demonstrate principles and techniques in reducing the risk of bleeding requiring transfusion in outpatient spine surgery.

\section{SUBJECTS AND METHODS}

We reviewed the database of a single spine surgeon in private practice between 2011 and 2015 and identified 1512 procedures performed in the outpatient setting. Procedures also done during this period, which were not considered for this study included, shoulder and knee arthroscopies, carpal tunnel release and lipoma excisions. All appropriate preoperative evaluations were conducted including, history and physical examinations, plain radiographs and magnetic resonance imaging, by the attending spine surgeon. A minimum of at least six weeks of conservative therapy was completed prior to consideration for surgery in all patients. Non-operative therapy included, anti-inflammatory medications, physical therapy, therapeutic steroid injections and, for patients with suspected facet-mediated axial back pain and radiofrequency rhizotomies. All patients were medically cleared by their family practitioners and/or specialists where applicable and regarded fit for surgery by the anaesthesiologists.

Two subgroups were created from all patients who had outpatient surgery, Group 1 (cervical spine) and Group 2 (lumbar spine). Analysis was performed using SPSS v. 22 (IBM Corp., New York, USA).

\section{Exclusions}

We excluded from our analysis, all cervical and lumbar epidural steroid injections as well as discograms, rhizotomies and non-spine orthopaedic procedures (total 812), which were considered minimally invasive non-surgical spinal procedures. There were 678 combined outpatient cervical and lumbar procedures remaining.

\section{Inclusions}

Inclusion criteria for outpatients was based-on previously published standard (9). Outcome measures evaluated were: age, BMI, length of surgery (LOS), estimated blood loss (EBL), 
total transfusions performed and comparison of incidence in single and multilevel procedures

\section{Less exposure surgery strategies}

Cervical surgery

- Avoid posterior cervical laminoplasty

- Perform limited laminectomy 1-3 levels combined with anterior discectomy and fusion

- Avoid lateral mass screws

- Use of bone wax

\section{Lumbar surgery}

- Avoid dissecting laterally past the pars to avoid pars artery

- Avoid full laminectomy unless severe spinal stenosis

a. Perform bilateral hemilaminectomies

- Use either cortical bone trajectory, percutaneous screws or facet screws for fusion

- Retain facet joint complex

- Perform lateral fusion under direct visualization

a. Split muscle fibres bluntly

b. Perform above L5

c. Utilize percutaneous screws to provide fixation

- Cauterize epidurals upon identification before bleeding

- Use of bone wax on bleeding bone edges

\section{RESULTS}

The study data revealed 700 total spine surgery cases, $300(43 \%)$ of all spine surgeries were performed in Group 1 (cervical spine) and 400 (57\%) in Group 2 (lumbar spine). Females represented $49 \%$ of the overall patient population (Group 1: 146, Group 2: 197). The mean overall age was $49.2 \pm 0.8$, mean age group 1 was $50.6 \pm 0.9$ and Group 2 was $47.1 \pm 1.2$. Mean overall BMI was $24 \pm 0.4$, Group 1 mean BMI was $21.0 \pm 0.7$ and Group 2 BMI was $26.1 \pm$ 0.3. Demographics are illustrated in Table 1.

Table 1: Demographic data of sample population

\begin{tabular}{lccc}
\hline Variable & Total & Cervical spine & Lumbar spine \\
\hline Surgeries & 700 & 300 & 400 \\
Male & 357 & 154 & 203 \\
Female & 343 & 146 & 197 \\
& & & \\
Single level & 477 & 181 & 296 \\
Multilevel & 233 & 119 & 104 \\
& Mean & & 47.1 \\
Age (years) & 49.2 & 50.6 & 26.1 \\
BMI (kg/m²) & 24.0 & 21.0 & 89 \\
LOS (mins) & 77.4 & 65.8 & 55.4 \\
EBL (mLs) & 52.4 & 43.3 &
\end{tabular}

BMI: body mass index; LOS: length of surgery; EBL:estimated blood loss

There were 244 cervical fusion and 56 cervical discectomy with annuloplasty performed in Group 1. In Group 2, there were a total of 133 fusions, 106 decompressions and interspinous fixations and 161 decompressions. Procedures performed are demonstrated in Table 2 and show overall fu- sions were significantly more than decompressions, $p<0.001$. Decompressions with interspinous fixation and discectomies were considered as decompressions.

Table 2. Demographic data of surgeries performed by level and type of surgery

\begin{tabular}{llcc}
\hline Surgeries & Total (n) & Cervical spine & Lumbar spine \\
\hline Single level & 477 & 181 & 296 \\
Fusion & 224 & 133 & 91 \\
Decompression & 253 & 48 & 205 \\
& & & \\
Multilevel* & 223 & 119 & 104 \\
Fusion & 153 & 111 & 42 \\
Decompression & 70 & 8 & 62 \\
\hline
\end{tabular}

The overall length of surgery was 77.4, group $1: 65.8 \pm 2.1$ and Group 2: $89.0 \pm 1.5$. The mean overall estimated blood loss was $52.4 \pm 1.7$, Group 1: $43.3 \pm 2.4$ and Group 2: $55.4 \pm$ 2.1. Further analysis to determine if blood loss was dependent on length of surgery, demonstrated significance, $p<0.0001$ with dependence $\mathrm{R}=0.451$.

The use of haemostatic agents was employed in all lumbar cases; however, this was not necessary in cervical cases. There were no blood transfusions or use of haemopoetic agents intra-operatively or postoperatively.

\section{DISCUSSION}

The aim of this study is to report on two groups of patients, who demonstrate the use of several surgical tips and techniques in decreasing blood loss thereby decreasing the risk of blood transfusion in elective outpatient spine surgery cases. In this study, a total of 700 outpatient spine cases were performed without the necessity to transfuse patients with blood in the peri-operative or postoperative periods. There was a statistically significant correlation between length of surgery and estimated blood loss, $p<0.0001$.

Elective surgery has demonstrated a change in management techniques over recent years (10). These changes include, improved patient selection, pre-operative workup, anaesthesia and surgical techniques $(2-4,7,10-12)$. The move towards ambulatory outpatient surgery has been driven by the factors of cost to patient, improved outcomes and decreased recovery time to normal function $(3,5)$. Blood loss is a major factor in surgical recovery with large volume blood losses increasing chances of transfusion and admission for observation $(1,11$, 13).

The impetus on spine surgeons to transition to the outpatient setting has been spurred by minimally invasive and less exposure surgery techniques $(4,9,11,14)$. Several studies have demonstrated the use of transexemic acid, bipolar sealer devices in reducing blood loss and transfusion requirement in surgery for scoliosis $(15,16)$. Other outpatient studies are available demonstrating surgical techniques with excellent or equivocal outcomes to inpatient surgery, with comparison of blood loss (3-5). However, few studies directly assess factors and techniques to reduce blood loss in spine surgery (11-13). The authors note several strengths and limitations to this 
study. Major strengths include that all surgeries were performed as outpatient cases in multiple centres. The total number of patients is adequate but no previous studies were found to conduct a priori power of analysis. This paper also adds to the volume of information available for outpatient spine surgery and risk-reduction in transfusion requirements. Limitation include, all cases were by a single surgeon who had prior experience in the inpatient setting and a single arm study design.

\section{CONCLUSION}

Advances in surgical techniques with the advent of less exposure surgery and minimally invasive spine surgery have demonstrated the need to reduce complications of blood loss requiring transfusion. This study has demonstrated the riskreduction for outpatient spine surgery using patient selection and improved surgical techniques.

\section{AUTHORS' NOTE}

Conflicts of interest and sources of funding: We did not seek or receive any funding from the National Institutes of Health (NIH), Wellcome Trust, Howard Hughes Medical Institute (HHMI), or others for this work. Dr. KR Chin is a shareholder in and receives other benefits from SpineFrontier Inc.; none of the other authors (FJRP, NTB, CFP, or JAS) have any potential conflicts of interest to declare for this work.

\section{REFERENCES}

1. Hu SS. Blood loss in adult spinal surgery. Eur Spine J 2004; 13 (Suppl 1): $\mathrm{S} 3-5$.

2. Butler JS, Burke JP, Dolan RT, Fitzpatrick P, O'Byrne JM, McCormack $\mathrm{D}$ et al. Risk analysis of blood transfusion requirements in emergency and elective spinal surgery. Eur Spine J 2011; 20: 753-8.

3. Chin KR, Coombs AV, Seale JA. Feasibility and patient-reported outcomes after outpatient single-level instrumented posterior lumbar interbody fusion in a surgery center: preliminary results in 16 patients. Spine 2015; 40: E36-42.
4. Chin KR, Pencle FJ, Coombs AV, Brown MD, Conklin KJ, O'Neill AM et al. Lateral lumbar interbody fusion in ambulatory surgery centers: patient selection and outcome measures compared with an inhospital cohort. Spine 2016; 41: 686-92.

5. Adamson T, Godil SS, Mehrlich M, Mendenhall S, Asher AL, McGirt MJ. Anterior cervical discectomy and fusion in the outpatient ambula tory surgery setting compared with the inpatient hospital setting: anal ysis of 1000 consecutive cases. J Neurosurg Spine 2016; 24: 876-84.

6. Outpatient Surgery: What is Outpatient Surgery? : EMedicineHealth; 2016.

7. Bess RS, Lenke LG. Blood loss minimization and blood salvage techniques for complex spinal surgery. Neurosurg Clin of N Am 2006; 17: 227-34.

8. Tobias JD. Strategies for minimizing blood loss in orthopedic surgery. Semin Hematol 2004; 41 (Suppl 1): 145-56.

9. Chin KR, Pencle FJ, Coombs AV, Packer CF, Hothem EA, Seale JA. Eligibility of outpatient spine surgery candidates in a single private practice. Clin Spine Surg 2017; 30: E1352-8.

10. Zambouri A. Preoperative evaluation and preparation for anesthesia and surgery. Hippokratia 2007; 11: 13-21.

11. Patel AA, Zfass-Mendez M, Lebwohl NH, Wang MY, Green BA, Levi $\mathrm{AD}$ et al. Minimally Invasive versus open lumbar fusion: a comparison of blood loss, surgical complications, and hospital course. Iowa Orthop J. 2015; 35: 130-4.

12. Tse EY, Cheung WY, Ng KF, Luk KD. Reducing perioperative blood loss and allogeneic blood transfusion in patients undergoing major spine surgery. J Bone Joint Surg Am 2011; 93: 1268-77.

13. Kumar N, Zaw AS, Khine HE, Maharajan K, Wai KL, Tan B et al. Blood Loss and Transfusion Requirements in Metastatic Spinal Tumor Surgery: Evaluation of Influencing Factors. Ann Surg Oncol 2016; 23: 2079-86.

14. Chin KR, Ricchetti ET, Yu WD, Riew KD. Less exposure surgery for multilevel anterior cervical fusion using 2 transverse incisions. J Neurosurg Spine 2012; 17: 194-8.

15. Sui W-y, Ye F, Yang J-1. Efficacy of tranexamic acid in reducing allogeneic blood products in adolescent idiopathic scoliosis surgery. BMC Musculoskeletal Disorders 2016; 17: 1-5.

16. Wang X, Sun G, Sun R, Ba C, Gong X, Liu W et al. Bipolar sealer device reduces blood loss and transfusion requirements in posterior spinal fusion for degenerative lumbar scoliosis: a randomized control trial. Clin Spine Surg 2016; 29: E107-11. 